International Journal of Clinical Therapeutics and Diagnosis (IJCTD)

ISSN 2332-2926

\title{
Study on Hepatitis B in Medical staff, Central Province, Islamic Republic of Iran
}

Research Article

Farahani $\mathrm{H}^{1}$, Zolfaghari $\mathrm{F}^{2}$

${ }^{1}$ Dept.of Biochemistry. Faculty of medicine, Arak University of Medical Sciences, IR. Iran.

${ }^{2}$ General Practitioner, Arak Medical Science University, Iran.

\section{Abstract}

Background: to determine the prevalence of $\mathrm{HBs} \mathrm{Ag}$ positive in staff of Amir Kabir Hospital (referral center) and compare with the results given by others.

Methods: 202 cases, working in Amir Kabir Hospital for more than 5 years were selected. ELISA Micro Plate Kit (Radim Company Italy) and Heponostrik kit were used for estimation. Positive samples were re-tested by the same method and confirm them by Iranian Blood Transfusion Organization, Arak branch.

Results: Our results showed that prevalence of infection to hepatitis B among Amir Kabir Hospital staff $2.9 \%$.The ratio of male to female were 2.4. However out of positive cases $83.4 \%$ were male and $16.6 \%$ female .All the positive cases had the previous contact with the blood or discharges of patients and needle.

Conclusion: The results of present study showed increment in infection of male staff to HBsAg as compared to the female. The rate of positive HBs Ag was $2.9 \%$, which showed increment as compared the results of $0.6-1.6 \%$ given by other

Keywords: Hepatitis B, Medical staff, I.R. Iran.

\section{*Corresponding Author:}

Dr. Farahani Heidar, M.Phil, Ph.D Biochemistry,

Associate Prof .Biochemistry, Dept. Biochemistry,Arak Medical Science

University,Arak, Central Province, Islamic Republic of Iran.

Tel: 09181611258; Fax: 08634173521

E-Mail; farahaniheidar@yahoo.com OR dr.farahanih@arakmu.ac.ir

Received: October 03, 2013

Accepted: October 30, 2013

Published: October 31, 2013

Citation: Farahani H, Zolfaghari F (2013) Study on Hepatitis B in Medical staff, Central Province, Islamic Republic of Iran. Int J Clin Ther Diagn. 1(3), 20-22. doi: http://dx.doi.org/10.19070/2332-2926-130004

Copyright: Farahani Heidar ${ }^{\circ}$ 2013. This is an open-access article distributed under the terms of the Creative Commons Attribution License, which permits unrestricted use, distribution and reproduction in any medium, provided the original author and source are credited.

\section{Introduction}

National Institute for Occupational Safety and Health reported that, there are approximately 600,000 to 800,000 needlestick and other percutaneous injuries every year among health care workers [1]. Hepatitis B infection is a worldwide health problem. According to one global survey, more than 2 billion people are infected with hepatitis B virus [2-4], and nearly 350 million are carrier for hepatitis $B$ virus[5]. In I.R.Iran infection is between $1 / 7$ to $5 \%$ $[6,7]$. Hepatitis $B$ is a major risk for staff that has frequent contacts with human blood or other body secretion of patients. Hepatitis B infection accounts annually for 1 million deaths worldwide from hepatocellular carcinoma and cirrhosis and liver failure $[1,8,9]$. Different studies have shown that medical staffs are at high risk for hepatitis B infection [9-12].There is still an ongoing discussion about the extent to which medical staff might be at risk of hepatitis B or source of hepatitis B infection [11,13-16].

The present study was designed to estimate seroepidemiology of HBs Ag positive in Amir Kabir Hospital(referral center of state for pediatric, ENT, Eye, Cardiology staff with nature of the unit given services to the patients, and a comparison with the results given by others.

\section{Materials and Methods}

A retrospective cross-sectional study was conducted on 202 staff, working for more than 5 years in different sensitive units in Amir Kabir Hospital such as operation hall, infectious ward, CCU, post CCU,ICU,OPD Operation hall, Laboratory ,emergency ( Nurses, Technicians and Cattes ) of these units were identified and participated in the study. Participant's age was 25 to 55 years . All participants completed a consent form, and tested the study protocol was approved by the research ethics committee of Arak Medical Science University. After informing the staff about the aim of the study, two to three milliliter blood sample was collected from the vein and tested for $\mathrm{HBs} \mathrm{Ag}, \mathrm{HBs} \mathrm{Ab}, \mathrm{HBc}, \mathrm{HBc}$ Ab. Estimation of $\mathrm{HBs} \mathrm{Ab}$ and $\mathrm{Hbs} \mathrm{Ag}$, within first 24 hour assayed ,using ELISA micro plate kits ( Radim company, Italy), and for $\mathrm{HBcAb}$ and Anti $\mathrm{HBc}$, kit of Heponostrik were used. Positive samples were re-tested second time by the same method and confirm them by Iranian Blood Transfusion Organization, arak. Those staff how were not agree to participate in this study (21 person) were excluded.

\section{Statistical Analysis:}

Data were analyzed by SPSS software version 11.5 . Data com- 
parisons were performed using the Chi-square, Fisher's exact test and Student's $t$ - test applied to test for significance at $95 \%$ confidence interval.

\section{Results}

Two hundred two person how worked for more than 5 years in Amir Kabir Hospital were tested. There were $29.8 \%$ male and $70.2 \%$ female. Findings showed that $15.8 \%$ of cases were unvaccinated and $84.2 \%$ were vaccinated (at least for two or three dose). 6 cases were $\mathrm{HBs}$ positive, that is prevalence of infection to hepatitis B among high risk personal in Amir Kabir Hospital in Arak, Central Province, was $2.9 \%$. Most of these positive cases were male $(83.4 \%)$ and $16.6 \%$ female. The male to female ratio was 2.4. Significantly prevalence of infection to hepatitis B in operation hall and cattes were higher than other ward staff. All positive cases $100 \%$ had the previous contact with the blood or discharges of patients and the needlestick. $50 \%$ of $\mathrm{HBs} \mathrm{Ag}$ positive cases had been unaware of previous hepatitis $B$ vaccine. (Table 1)

\section{Conclusions}

Exposure to blood and other potentially infectious body fluids have, for long time been recognized as a potential health hazard in health care personnel. On the basis of the present study, the rate of positive HBs $\mathrm{Ag}$ was $2.9 \%$, which showed increment as compared the results of $0.6-1.6 \%$ given by other in I.R. Iran[1618].This difference may be due to nature of hospital which contents Eye, ENT, Cardiology, and pediatric wards . Injuries from sharp objects among staff are widespread occupational hazard. In this study sex and specific wards were most important risk factors for infected personnel. $50 \%$ of $\mathrm{HBs}$ positive in our investigation had not been vaccinated previously. So an effective educational program and an establishment of surveillance system for registering and management of occupational exposure in hospital are needed. Even today we observed staff unaware of their vaccination [18-20]. So implementation of awareness strategies is urgent and the need of boosters among health care workers to be essential.

Table 1. Comparisons between Prevalence of HBsAg and risk factor in Medical staff, Central Province, IR. Iran (Total number of cases $=202$ )

\begin{tabular}{|l|l|l|l|}
\hline Risk factor & Total No. individuals and \% & Total No. HBsAg + & $\begin{array}{l}\text { Prevalence } \\
\text { Percentage }\end{array}$ \\
\hline $\begin{array}{l}\text { Contact with patient blood or dis- } \\
\text { charges }\end{array}$ & $177(87.6 \%)$ & 6 & 2.9 \\
\hline Needle injection & $147(72.8 \%)$ & 6 & 2.9 \\
\hline $\begin{array}{l}\text { Contact eye with patient blood or } \\
\text { discharges }\end{array}$ & $68(33.6 \%)$ & 2 & 1 \\
\hline Blood Transfusion & $3(1.5 \%)$ & 0 & 0 \\
\hline Tattoo & $13(6.4 \%)$ & 1 & 0.5 \\
\hline Sex Male & & & 2.45 \\
\hline \multicolumn{1}{|c|}{ Female } & $59(29.2 \%)$ & $5(83.4 \%)$ & 0.55 \\
\hline Vaccinated & $143(70.8 \%)$ & $1(16.6 \%)$ & 1.45 \\
\hline Unvaccinated & $170(84.2 \%)$ & $3(50 \%)$ & 1.45 \\
\hline
\end{tabular}

\section{Acknowledgement}

We thank the personal of Amir Kabir Hospital in Arak, Central Province of IR Iran for their precipitance in present study. The authors also thank the vice chancellor for research, Arak University of medical sciences IR Iran, for sponsoring this project.

\section{References}

[1]. Blasius KR, Neustein SM . An unexpected needlestick injury. Middle East J Anesthesiol.2012: 21(5):751-2.

[2]. Pruss-Ustun A, Rapiti E, Hutin Y (2005). Estimation of the global burden of disease attributable to contaminated sharps injuries among health-care workers. Am J Ind Med.2005: 48(6):482-90.

[3]. Mohammad Hassan Kazemi Galougahi . Evaluation of needle stick injuries among nurses of Khanevadeh Hospital in Tehran. Iran J Nurs Midwifery Res.2010: 15(4): 172-177.

[4]. Jules L. Dienstag M.D. Hepatitis B Virus Infection, N. Eng. J. Medicine. 2008:359(14):1486-1500

[5]. Lavanchy D. Hepatitis B virus epidemiology, disease burden, treatment, and current and emerging prevention and control measures. J Viral Hepat; 2004:11: 97-107.

[6]. Malek zadeh R. Bill and Liver diseses, 7th chapter,Tehran, 1997:p129-169
[7]. Askarian M, Malekmakan L. The prevalence of needle stick injuries in medical, dental, nursing and midwifery students at the university teaching hospitals of Shiraz, Iran. Indian J Med Sci.2006: 60(6):227-32

[8]. Shah SM. Bonauto B. Floey M.Workers compensation claims for needle stick injuries among health care workers in Washington state.1996-2000. Infect.Control Hosp. Epidemiol.2005: 26(9):775-781

[9]. Mobacherizadeh S. Abne-Shahidi SA, Mohammadi NA.Abazari F. Intervention study on needle stick injury in Iran .Saudi Med. J.2005: 26(8):12251227

[10]. Askarian M, Yadollahi M, Kuochak F, Danaei M, Vakili V, Momeni M. Precautions for health care workers to avoid hepatitis $B$ and $C$ virus infection. Int J Occup Environ Med.2011: 2(4):191-8.

[11]. Phillips EK, Simwale OJ, Chung MJ, Parker G, Perry J, Jagger JC. Risk of bloodborne pathogen exposure among Zambian healthcare workers. J Infect Public Health. 2012:5(3):244-9.

[12]. Azap A, Ergönül O, Memikoğlu KO, Yeșilkaya A, Altunsoy A, Bozkurt GY, Tekeli E. Occupational exposure to blood and body fluids among health care in Ankara, Turkey, Am. J. Infect. Control,2005: 33; 48-52

[13]. Jahan S. Epidemiology of needlestick injuries among health care workers in a secondary care hospital in Saudi Arabia. Ann Saudi Med.2005:25:233-238

[14]. Pournaras S, Tsakris A, Mandraveli K, Faitatzidou A, Douboyas J, Tourkantonis A. Reported needle stick and sharp injuries among health care workers in a Greek general hospital. Occup. Med. (lond).1999: 49; 423-426

[15]. Poujol I, Floret N, Sevant -Delmas A, Marquqnt A, Laperches S, and Antona D.Hepatitis B virus transmission from nurse to a patient, France. Eurosurveillance, 2008; vol 13, issue 21

[16]. Ahmad Zadeh MZ.Study on prevalence of HBsAg in personnel of Imam 
Khomeini Hospital, Sages, 1999-2000; Kurdistan Medical Science J. 2000 : 5 (11): 78-79

[17]. Lotfi R, Gashtasbi A. Needle stick and sharps injuries and its risk factors among health center personnel (Astara; Iran, 2006) Journal of Babol University of Medical Sciences. 2008: 10(4):71-7.

[18]. Nasiri E, Mortazavi Y, Mortazavi Y, Siamian H, Siamian H, Shaaban khani B. The prevalence and study of the rate of needle stick injuries infected by blood in staffs of special departments of teaching and non-teaching hospitals of Mazandaran province in 2003-2005. Iranian Journal of Infectious Diseases and Tropical Medicine; 2005 : (10):29-41.

[19]. Hadadi A, Afhami S, Karbakhsh M,Esmailpour N. Occupational exposure to body fluids among health care workers, a report from Iran. Singapore Med. J. 2008: 49(6):492-496

[20]. Ganczak M , Bohatyrewic A, Szych Z. Blatecki P. Markers of hepatitis B, C and HIV among orthopedic patients and staff at a Polish University hospital. (abstract in English).Chir Narzadow Ruchu Ortop. Pol. 2008: 73(2):83-88 